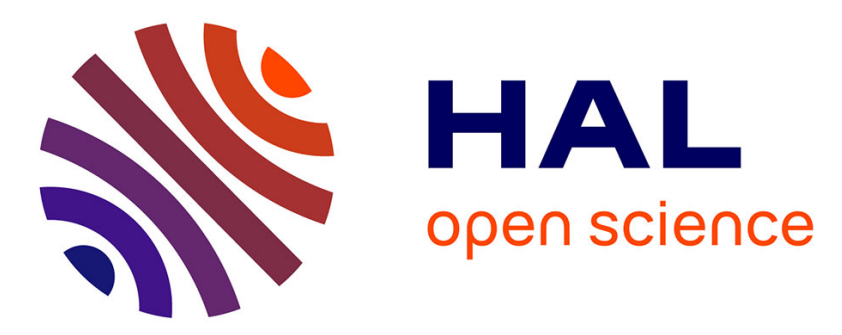

\title{
Response Surface Methodology for Enzyme-Assisted Extraction of Water-Soluble Antiviral Compounds from the Proliferative Macroalga Solieria chordalis
}

Anne-Sophie Burlot, Gilles Bedoux, Nathalie Bourgougnon

\section{To cite this version:}

Anne-Sophie Burlot, Gilles Bedoux, Nathalie Bourgougnon. Response Surface Methodology for Enzyme-Assisted Extraction of Water-Soluble Antiviral Compounds from the Proliferative Macroalga Solieria chordalis. Enzyme Engineering, 2016, 5 (2), pp.1000148. 10.4172/2329-6674.1000148 . hal01370461

\author{
HAL Id: hal-01370461 \\ https://hal.science/hal-01370461
}

Submitted on 22 Sep 2016

HAL is a multi-disciplinary open access archive for the deposit and dissemination of scientific research documents, whether they are published or not. The documents may come from teaching and research institutions in France or abroad, or from public or private research centers.
L'archive ouverte pluridisciplinaire HAL, est destinée au dépôt et à la diffusion de documents scientifiques de niveau recherche, publiés ou non, émanant des établissements d'enseignement et de recherche français ou étrangers, des laboratoires publics ou privés. 


\title{
Enzyme Engineering
}

\section{Response Surface Methodology for Enzyme-Assisted Extraction of Water- Soluble Antiviral Compounds from the Proliferative Macroalga Solieria chordalis}

\author{
Burlot Anne-Sophie*, Bedoux Gilles and Bourgougnon Nathalie
}

Université de Bretagne Sud, Laboratoire de Biotechnologie et Chimie Marines, Campus de Tohannic - BP 57356017 Vannes, Cedex, France

\begin{abstract}
Macroalgal blooms frequently occur in France. On a part of the coastline, these algal blooms are mainly composed of red seaweeds like Solieria chordalis and constitute an unexploited significant natural biomass. In this study, active compounds from Solieria chordalis were extracted and evaluated as a potential source of natural antivirals, coupling biotechnological development with economic and ecological benefits. In order to extract in water the highest quantity of potential active compounds, a sustainable process was developed, namely the enzymeassisted extraction. The quantity of water-soluble compounds increased by $30 \%$ after the addition of enzymes, in comparison with an aqueous extraction. The optimization of conditions using a response surface methodology improved the yield and allowed to study the influence of different extraction parameters simultaneously, notably the nature and the quantity of enzymes, the temperature and the time of extraction. This latter parameter was the most influent on extraction yield with the nature of the enzyme. The best antiherpetic activity was obtained with the extract after the action of a type of proteases with an EC50 of $86.0 \mu \mathrm{g} . \mathrm{mL}^{-1}$. Moreover, a positive correlation between sulfated polysaccharides and the antiviral activity of extracts was demonstrated. For the first time, soft biotechnology with enzymes using surface response methodology has been performed in order to obtain water-soluble antiviral extracts from the red proliferative seaweed Solieria chordalis.
\end{abstract}

Keywords: Antibiotics; Bacteria; Popular knowledge; Metabolism; Natural products

Abbreviations: EAE: Enzyme-Assisted Extraction; HSV-1: Herpes Simplex Virus Type 1; WSE: Water-Soluble Extract.

\section{Introduction}

Excessive growths reported for some species of green, brown and red seaweeds are responsible for the recent formation of harmful marine macroalgal blooms worldwide. Local wind and tides drive seaweeds to the shore, causing the destruction of coastal marine habitats and economical losses. Each year, in South Brittany, in France, over 2,000 tons of red seaweeds, mainly composed of Solieria chordalis, have to be removed [1].

Largely unexploited, $S$. chordalis holds considerable potential for biotechnological development, since some of its polymers have already been shown to possess immunological, haemagglutinic, and antiviral activities with practical application in biomedicine $[2,3]$.

In addition to the compounds inside seaweed cells, there are other potential active components associated with the cell walls [4]. To isolate these metabolites of interest, the cell wall must be cleaved, but the presence of large quantities of various interconnected polysaccharides and their bonding with proteins reduces the efficiency of the standard extraction methods used to date (e.g. organic and water extractions) [5]. Enzyme-assisted extraction (EAE) is an environmentally friendly extraction method known by its high efficiency and reduced solvent consumption and time [4]. In this regard, proteins, especially enzymes from marine and terrestrial microorganisms, are used to release in water the maximum number of compounds from seaweeds, thus improving their availability and their digestibility for animals, humans, or plants $[5,6]$.

Numerous studies have shown the benefits of using enzymes to add value to seaweed extracts or compounds [3,4,7], but only a few deal with the optimization of hydrolysis conditions on algal material
[5]. Parameters such as the time needed for the enzymatic hydrolysis, temperature, nature and concentration of enzymes, $\mathrm{pH}$, and raw material pretreatment have shown their impact on the extraction [8]. Response surface methodology is based on the fit of statistical models to measured data obtained in relation to an experimental design. This methodology has been shown to be useful for improving, developing, and optimizing biochemical processes to extract the maximum number of compounds of interest [8]. The Box-Behnken design was chosen to investigate the influence of three parameters on the extraction yield of water-soluble compounds, notably the time of extraction, the temperature, and the enzyme quantity used on dried seaweeds.

In this study, the isolation of antiviral extracts from the red macroalga Solieria chordalis was performed by using enzymes. After selecting the most efficient enzyme in the release of antiviral compounds, an experimental design procedure was used to increase the extraction yield.

\section{Materials and Methods}

\section{Algal material}

About $20 \mathrm{~kg}$ of S. chordalis (Rhodophyta, Gigartinales) were collected in October 2013 from the littoral zone of Saint Gildas de Rhuys in Brittany, France. Seaweeds were washed with tap water. They

*Corresponding author: Burlot Anne-Sophie, Université de Bretagne Sud, Laboratoire de Biotechnologie et Chimie Marines, Campus de Tohannic - BP 57356017 Vannes, Cedex, France, Tel: (+33) 29701 72 53; E-mail: anne-sophie.burlot@univ-ubs.fr

Received June 26, 2016; Accepted July 26, 2016; Published July 29, 2016

Citation: Anne-Sophie B, Gilles B, Nathalie B (2016) Response Surface Methodology for Enzyme-Assisted Extraction of Water-Soluble Antiviral Compounds from the Proliferative Macroalga Solieria chordalis. Enz Eng 5: 148. doi:10.4172/2329-6674.1000148

Copyright: (C) 2016 Anne-Sophie B et al. This is an open-access article distributed under the terms of the Creative Commons Attribution License, which permits unrestricted use, distribution, and reproduction in any medium, provided the original author and source are credited. 
were scraped and drained to remove adherent seawater, sediment and epiphytes. Cleaned and wrung out seaweeds were ground to pieces of 3 $\mathrm{mm}$ with a hammer mill prior to freeze drying.

\section{Enzymes}

Eight commercial enzyme solutions from Novozymes (Le Pecq, France) were separately evaluated for the extraction of S. chordalis: three proteases (subtilisin, neutral metallo-proteinase and exopeptidase) that are named P1 to P3 and five carbohydrases (amyloglucosidase, alphaamylase, endo-xylanase, endo-beta-glucanase, polygalacturonase betaglucanase) that are named $\mathrm{C} 1$ to $\mathrm{C} 5$ respectively.

\section{Cells and virus}

African green monkey kidney cells (ATCC CCL-81) were grown in Eagle's minimum essential medium (MEM, Eurobio, Courtaboeuf, France) supplemented with $8 \%$ fetal calf serum (FCS, Eurobio) and $1 \%$ of antibiotics $\left(10,000 \mathrm{IU} \mathrm{mL}^{-1}\right.$ penicillin, 25,000 IU mL $\mathrm{mL}^{-1}$ colimycin, 10 mg.mL ${ }^{-1}$ streptomycin, Sigma Aldrich).

HSV-1 (Herpes Simplex Virus type 1, wild type strain 17) was obtained from Pr. Agut, Laboratoire de Dynamique, épidémiologie et traitement des infections virales in Pitié Salpétrière (Paris, France). Viruses are stored in infected Vero cells bathing in supplemented MEM at $-80^{\circ} \mathrm{C}$ before use.

\section{Extractions}

To characterize the raw matter of $S$. chordalis, $10 \mathrm{mg}$ of freezedried matter were mixed with $5 \mathrm{~mL} \mathrm{HCl} 1 \mathrm{M}$ in a sealed vial. The acid extraction was performed at $100^{\circ} \mathrm{C}$ for $2 \mathrm{~h}$, after which $5 \mathrm{~mL} \mathrm{NaOH}$ $1 \mathrm{M}$ were added. The final solution was used to measure the neutral sugars, uronic acids, and proteins contents. To analyze the sulfate groups linked to polysaccharides, the same conditions of extraction were performed in ultrapure water.

EAE was achieved in a final volume of $300 \mathrm{~mL}$ with $19.5 \mathrm{~g}$ of freezedried matter of $S$. chordalis and the rest with distilled water. Enzymes $(5 \% \mathrm{dw} / \mathrm{dw})$ were added to the mixture that is incubated at $50^{\circ} \mathrm{C}$. Extractions were carried out for 3 hours. Enzymes were then denatured at $85^{\circ} \mathrm{C}$ for $15 \mathrm{~min}$. The obtained water-soluble extracts (WSE) were filtered, separated from the washed residue and freeze-dried. A blank extracted in the same conditions $\left(3 \mathrm{~h}, 50^{\circ} \mathrm{C}\right)$ but without enzymes served as a control. Each extraction was performed in triplicate.

\section{Extraction yield determination}

The EAE yield represents the proportion, in percentage, of the dry weight of $S$. chordalis found in the WSE. The dry weight of WSE was determined gravimetrically after incubation at $100^{\circ} \mathrm{C}$ overnight.

\section{Biochemical composition analysis}

The composition of $S$. chordalis and of WSE is defined as the proportions in percentage of each chemical compound family found in the total dried weight of the raw matter or of WSEs. All the biochemical analyses were carried out in triplicate. Neutral sugars were determined by the phenol sulphuric acid method described by Dubois et al. [9] Uronic acids were determined by using the meta-hydroxy-di-phenyl (MHDP) method [10]. Sulfated groups content was determined by the Azure A method that reacts specifically with sulfates linked to the polysaccharides [11]. Lipids were extracted with a mixture of chloroform/methanol $(1: 1, \mathrm{v} / \mathrm{v})$ over 2 days under agitation. The extract was filtered and washed with distilled water. The lipid content was determined gravimetrically. Proteins were quantified by the bicinchoninic acid colorimetric method (BCA) with a Micro BC Assay Kit (Interchim, Montluçon, France) [12]. Ash values were determined gravimetrically after incineration of samples followed by $2 \mathrm{~h}$ at $700^{\circ} \mathrm{C}$.

\section{Cytotoxicity and antiherpetic activity}

Dilutions of samples $(1 \mu \mathrm{g} / \mathrm{mL}$ to $200 \mu \mathrm{g} / \mathrm{mL})$ were prepared in Eagle's MEM supplemented with $8 \%$ FCS and distributed into a $96-$ well plate. One hundred microliters of cellular suspension $(3.5 \times 105$ Vero mammalian cells $/ \mathrm{mL}$ ) in supplemented Eagle's MEM were added in each well. In half of the microplate, cells were infected by the HSV1 (Herpes Simplex Virus type 1) at a multiplicity of infection of 0.001 ID50/cells. The last two columns of the 96-well plate were used for the controls of the living cells and infected cells by HSV-1. The 96-well plate was incubated for 3 days at $37^{\circ} \mathrm{C}$ with $5 \% \mathrm{CO}_{2}$.

Cytotoxicity was tested using cell viability by the neutral red dye method. Optical density (OD) was measured at $540 \mathrm{~nm}$. The $50 \%$ cytotoxic concentration (CC50) was defined as the concentration of seaweed extract that reduced the OD of treated cells to $50 \%$ of that of untreated cells [13].

The antiherpetic compound acyclovir was used as reference inhibitor. The $50 \%$ effective antiviral concentration (EC50) was expressed as the concentration that achieved $50 \%$ protection of virusinfected cells [13].

\section{Experimental design for the optimization}

Three parameters were examined: the time of the extraction, the temperature, and the ratio of enzyme on substrate (E/S). They were varied into three levels. The measured response was the extraction yield of water soluble compounds. A total of 13 experiments were performed in triplicate (Table 1). The order of the experiments was fully randomized. To check the model predicted by the statistical analyses, experiments were conducted (Table 1).

\section{Statistical analysis}

Results are expressed as mean \pm standard deviation (SD). The statistical analyses were carried out with the software Minitab 17 using one-way analysis of variance (ANOVA) according to the Fisher's Least Significant Difference (LSD) test at $5 \%$ level to evaluate the differences between extracts or extraction parameters.

\section{Results}

\section{Biochemical composition of S. chordalis}

The biochemical composition of the red macroalga $S$. chordalis is given in Table 2.

S. chordalis is composed essentially of water up to $90 \%$. The dry matter is rich in ash $(43.3 \%)$ and in sulfated polysaccharides (a little less than $49.5 \%$ if the neutral sugars, sulfate groups, and uronic acids contents are gathered and taking in account interferences between compounds during the biochemical assays). Lipids represented a small percentage of the dry weight of the macroalgae (3.0\%). Proteins constituted over one fifth of the dry matter $(22 \%)$.

\section{Screening of enzymes}

The effect of the different enzymes on the extraction yield is shown in Figure 1.

All WSEs, after the action of enzymes, contain quantitatively more compounds than the blank. The protease P1 is significantly the most 


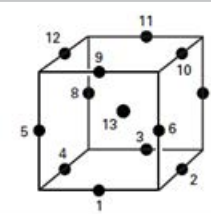

\begin{tabular}{|c|c|}
\hline Levels of independent variables used & Extraction time (min) \\
\hline-1 & 90 \\
\hline 0 & 180 \\
\hline 1 & 270 \\
\hline
\end{tabular}

mperature $\left({ }^{\circ} \mathrm{C}\right)$
25
37.5
50

\section{E/S (\% DW algae)}

$\mid 37$

Table 1: Box-Behnken experimental design and levels of independent variables used to optimize the enzyme-assisted extraction

\begin{tabular}{|c|c|c|c|c|c|c|}
\hline Dry weight & Ash content & Proteins & Lipids & Uronic acids & Sulfate groups & Neutral sugars \\
\hline$(\% F W)^{a}$ & $(\% D W)^{b}$ & $(\% D W)^{b}$ & $(\% D W)^{b}$ & $(\% D W)^{b}$ & $(\% D W)^{b}$ & $(\% D W)^{b}$ \\
\hline $10.0 \pm 0.6$ & $43.3 \pm 3.1$ & $22.0 \pm 2.0$ & $3.0 \pm 0.1$ & $3.1 \pm 0.1$ & $14.7 \pm 1.0$ & $31.7 \pm 0.7$ \\
\hline
\end{tabular}

Table 2: Dry weight and biochemical composition of S. chordalis.

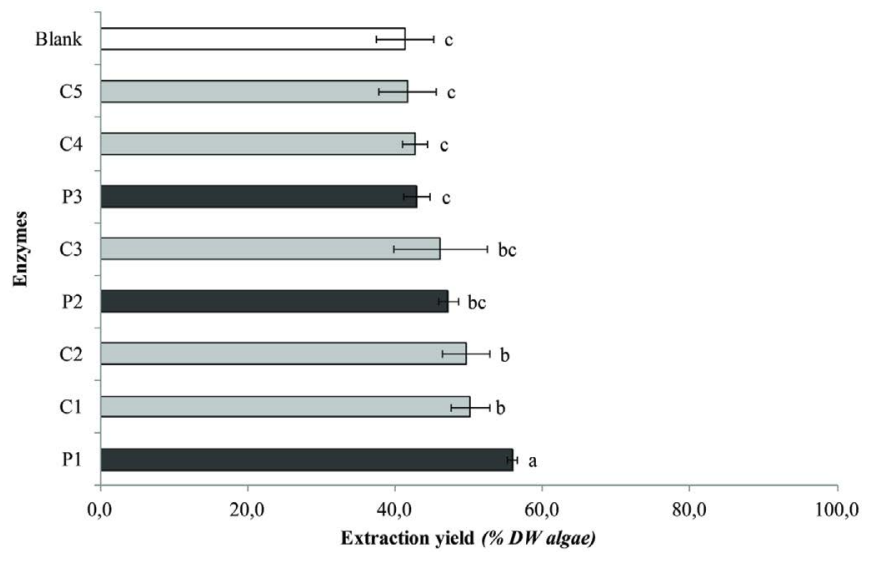

Figure 1: Extraction yield of WSEs from $S$. chordalis $\left(180 \mathrm{~min}, 50^{\circ} \mathrm{C}, 5 \%\right.$ enzyme). [Values are means $\pm S D(n=9)$. Values with different superscript letters are significantly different $(p<0.05)$ according to the Fisher LSD test WSEs after action of proteases are indicated by black bars; WSEs after action of carbohydrases by light grey bars; water extract by the white bar. The order of letters is correlated with the extraction yield].

efficient in the release of water-soluble compounds as the extraction yield reached almost $60 \%(55.8 \%)$. The gain of the released compounds found in the WSE due to the action of $\mathrm{P} 1$ is $30 \%$, compared to an aqueous extraction in the same conditions (Blank). Extraction yields after the action of carbohydrases $\mathrm{C} 1$ to $\mathrm{C} 3$ and of the protease $\mathrm{P} 2$ are not significantly different and are between 46.1 and $50.1 \%$, but only $\mathrm{C} 1$ and $\mathrm{C} 2$ increased significantly the yield compared to the blank. The others enzymes (C4, C5, and P3) and the blank obtained a similar yield between 41.3 and $43.0 \%$ of the total compounds present in S. chordalis.

\section{Biochemical compositions of extracts}

The proportions of water-soluble compounds composing the dry weight of WSEs are presented in Table 3. To measure the rates of the different compounds families, no acid or water extraction was performed. Only the available and free compounds of the extracts were then considered. In the last column titled Others, no identified compounds are found. They may correspond to agglomerates, or other compounds that are not detected by the biochemical analyses used. All enzyme-assisted extractions solubilized an important proportion of ash from 55.0 to $64.2 \%$. Nevertheless, more organic matter was extracted due to the action of enzymes. Less than $20 \%$ organic matter was found in the blank and up to $45 \%$ after the action of enzymes. In the soluble extracts, between 9.1 and $33.3 \%$ of neutral sugars were obtained, whereas only 4.5 to $8.9 \%$ of proteins were present. Few sulfate groups ( 1.6 to $4.2 \%$ ) as well as uronic acids ( 0.2 to $1.3 \%$ ) were detected. The proteases $\mathrm{P} 1$ and $\mathrm{P} 2$ allowed to access to the highest proportions of proteins ( 8.9 and $8.8 \%$ of the dry matter) and the carbohydrase C5 to the highest proportion of neutral sugars (33.3\%) followed by P1 (27.5\%) (Table 3).

\section{Cytotoxicity and antiviral activity}

After 3 days of viral infection, visible alteration of normal cell morphology was observed under the microscope except for the cells in contact with seaweed extracts. No cytotoxic effect on Vero cells was detected for all the WSEs for a $\mathrm{CC}_{50}$ inferior to $200 \mu \mathrm{g} \cdot \mathrm{mL}^{-1}$ (Table 4). The lowest $\mathrm{EC}_{50}$ that represents the most efficient antiviral activity was obtained with the P1 extract $\left(86.0 \mu \mathrm{g} . \mathrm{mL}^{-1}\right)$ followed by the extracts obtained with P3 and with carbohydrases (C1, C2, C5 and $\mathrm{C} 3$ respectively). The $\mathrm{P} 2$ extract showed the least efficient antiherpetic activity with an $\mathrm{EC}_{50}$ of $145.9 \mu \mathrm{g} \cdot \mathrm{mL}^{-1}$ and was not significantly different than those measured in the blank $\left(170.7 \mu \mathrm{g} \cdot \mathrm{mL}^{-1}\right)$ (Table 4).

\section{Optimization by Box-Behnken design}

The protease $\mathrm{P} 1$ was selected for optimizing extraction conditions in order to increase potentially the active compounds quantity. The responses that correspond to extraction yields following different conditions of enzymatic digestion are reported in (Table 5).

Three enzyme-assisted extraction conditions significantly resulted in a similar quantity of compounds in extracts (Experiments $\mathrm{N}^{\circ} 3,10$ and 11$)$ with a maximum extraction yield of $59.4 \%\left(\mathrm{~N}^{\circ} 11\right)$. Compared to the screening conditions with $\mathrm{P} 1$, the yield increased by $6.5 \%$ with $7.5 \%$ enzymes on dry matter of $S$. chordalis during the same time (180 $\min$ ) and at the same temperature $\left(50^{\circ} \mathrm{C}\right)$. An extraction time from $180 \mathrm{~min}$ to $270 \mathrm{~min}$ was necessary to reach a maximum number of water soluble compounds. Moreover, $90 \mathrm{~min}$ were not sufficient to break down the cell walls, regardless of the other examined parameters. The highest tested temperature $\left(50^{\circ} \mathrm{C}\right)$ enabled the extraction of a maximum number of compounds during $180 \mathrm{~min}$. Nevertheless, at 25 and $37.5^{\circ} \mathrm{C}$, relatively good extraction yields were measured (52.4 to $56.5 \%)$. Concerning the relation $\mathrm{E} / \mathrm{S}$, for two of the best conditions, extractions assisted with $7.5 \%$ of $\mathrm{P} 1$ were the most efficient.

\section{Predicted optimal extraction conditions}

According to the response obtained for each experiment (Table 5), the best explanatory model equation for the enzyme-assisted extraction yield (EAE \%) with $T$, the temperature $\left({ }^{\circ} \mathrm{C}\right), t$, the time (min) and $E / S$ the enzyme on substrate ratio (\%) was: 
Citation: Anne-Sophie B, Gilles B, Nathalie B (2016) Response Surface Methodology for Enzyme-Assisted Extraction of Water-Soluble Antiviral Compounds from the Proliferative Macroalga Solieria chordalis. Enz Eng 5: 148. doi:10.4172/2329-6674.1000148

Page 4 of 8

\begin{tabular}{|c|c|c|c|c|c|c|}
\hline & Neutral sugars & Sulfate groups & Uronic acids & Proteins & Ash & Others \\
\hline & $(\% D W)$ & $(\% D W)$ & $(\% D W)$ & $(\% D W)$ & $(\% D W)$ & $(\% D W)$ \\
\hline Blank & g $12.8 \pm 0.1$ & f $1.6 \pm 0.4$ & b $1.0 \pm 0.1$ & ${ }^{\mathrm{d}} 4.5 \pm 0.1$ & a $70.9 \pm 1.0$ & $\begin{array}{c}\mathrm{b} 9.2 \\
\pm \\
1.7\end{array}$ \\
\hline $\mathrm{C} 1$ & ${ }^{\mathrm{d}} 22.8 \pm 0.9$ & ab $3.7 \pm 0.2$ & ${ }^{\mathrm{c}} 0.6 \pm 0.1$ & ${ }^{a b c} 8.4 \pm 0.6$ & ${ }^{\mathrm{b}} 64.2 \pm 0.4$ & ${ }^{\mathrm{c}} 0.3 \pm 2.1$ \\
\hline $\mathrm{C} 2$ & cd $24.1 \pm 1.3$ & cd $2.7 \pm 0.3$ & b $1.0 \pm 0.1$ & abc $7.8 \pm 0.8$ & $\begin{array}{c}\text { d } 55.0 \\
\pm \\
0.9\end{array}$ & b $9.4 \pm 3.4$ \\
\hline $\mathrm{C} 3$ & e $19.9 \pm 0.8$ & ${ }^{\mathrm{b}} 3.4 \pm 0.3$ & ${ }^{\mathrm{d}} 0.2 \pm 0.1$ & ${ }^{\mathrm{c}} 7.1 \pm 0.1$ & ${ }^{\mathrm{b}} 64.0 \pm 4.4$ & bc $5.4 \pm 5.7$ \\
\hline $\mathrm{C} 4$ & h $9.1 \pm 1.5$ & de $2.3 \pm 0.3$ & b $1.1 \pm 0.1$ & d $5.3 \pm 0.2$ & $\begin{array}{c}{ }^{\mathrm{b}} 64.0 \\
\pm \\
4.6\end{array}$ & a $18.3 \pm 6.7$ \\
\hline C5 & a $33.3 \pm 0.8$ & b $3.3 \pm 0.1$ & ${ }^{\mathrm{d}} 0.2 \pm 0.1$ & ab $8.5 \pm 0.7$ & bcd $58.9 \pm 2.4$ & ${ }^{\mathrm{c}} 0.1 \pm 4.1$ \\
\hline $\mathrm{P} 1$ & b $27.5 \pm 0.3$ & ${ }^{\mathrm{bc}} 3.2 \pm 0.1$ & ${ }^{\mathrm{d}} 0.3 \pm 0.2$ & a $8.9 \pm 2.0$ & ${ }^{\mathrm{cd}} 56.5 \pm 1.6$ & ${ }^{\mathrm{bc}} 3.6 \pm 4.2$ \\
\hline $\mathrm{P} 2$ & f $17.6 \pm 0.8$ & ef $1.9 \pm 0.2$ & a $1.3 \pm 0.1$ & a $8.8 \pm 0.4$ & bc $61.2 \pm 6.6$ & b $9.3 \pm 8.1$ \\
\hline P3 & ${ }^{\mathrm{c}} 25.4 \pm 1.2$ & $4.2 \pm 0.5$ & ${ }^{\mathrm{c}} 0.5 \pm 0.1$ & bc $7.3 \pm 0.3$ & b $63.9 \pm 0.5$ & ${ }^{\mathrm{c}} 0.1 \pm 2.6$ \\
\hline
\end{tabular}

Values are means $\pm S D(n=9)$

For each column, values with different superscript letters are significantly different $(p<0.05)$ according to the Fisher LSD test. The order of letters is correlated with the compounds contents.

Table 3: Biochemical composition of extracts after the action of different enzymes $\left(180 \mathrm{~min}, 50^{\circ} \mathrm{C}, 5 \%\right.$ enzyme).

\begin{tabular}{|c|c|c|}
\hline & $\mathrm{CC}_{50}$ & $\mathrm{EC}_{50}$ \\
\hline & $(\mu g / m L)$ & $(\mu g / m L)$ \\
\hline $\mathrm{P} 1$ & $>200 \pm 0.9$ & a $86.0 \pm 9.1$ \\
\hline P3 & $>200 \pm 0.8$ & a $96.7 \pm 4.7$ \\
\hline $\mathrm{C} 1$ & $>200 \pm 3.3$ & a $98.6 \pm 7.1$ \\
\hline $\mathrm{C} 2$ & $>200 \pm 1.0$ & ab $109.8 \pm 12.1$ \\
\hline C5 & $>200 \pm 2.4$ & ${ }^{a b} 110.0 \pm 6.5$ \\
\hline $\mathrm{C} 3$ & $>200 \pm 0.1$ & ab113.7 \pm 19.1 \\
\hline $\mathrm{C} 4$ & $>200 \pm 2.4$ & bc136.2 146.3 \\
\hline $\mathrm{P} 2$ & $>200 \pm 9.6$ & cd $145.9 \pm 12.2$ \\
\hline Blank & $>200 \pm 1.3$ & $\mathrm{~d} 170.7 \pm 11.9$ \\
\hline Drug (acyclovir) & $>200 \pm 0.2$ & ${ }^{\mathrm{d}} 0.5 \pm 0.4$ \\
\hline \multicolumn{3}{|c|}{$\begin{array}{l}\left.\text { MOI: multiplicity of infection of } 0.001 \mathrm{ID}_{50} / \text { cells: ratio (virus titer)/ (cells numbers } \mathrm{mL}-1\right) \text {. } \\
\mathrm{CC}_{50} \text { : the } 50 \% \text { cytotoxic concentration. The concentration that reduced the absorbance of mock-infected cells to } 50 \% \text { of that of control. } \\
\mathrm{EC}_{50} \text { : the } 50 \% \text { antiviral effective concentration: concentration that achieved } 50 \% \text { protection of virus-infected cells from the HSV-induced destruction. } \\
\text { Values are means } \pm \mathrm{SD}(\mathrm{n}=8) \text {. } \\
\text { Values with different superscript letters are significantly different }(\mathrm{p}<0.05) \text { according to the Fisher LSD test. The order of letters is correlated with the efficiency of activity }\end{array}$} \\
\hline
\end{tabular}

Table 4: Evaluation of anti-HSV-1 activity on Vero cell line of WSEs from S. chordalis, by neutral red dye method.

\begin{tabular}{|c|c|c|c|c|}
\hline \multirow{2}{*}{$\begin{array}{c}\text { Experiment } \\
\mathrm{N}^{\circ}\end{array}$} & \multicolumn{3}{|c|}{ Hydrolysis conditions } & \multirow{2}{*}{$\begin{array}{c}\text { Obtained response } \\
\text { EAE yield extraction } \\
\text { ( } \% d w \text { algae })\end{array}$} \\
\hline & Extraction time (min) & Temperature $\left({ }^{\circ} \mathrm{C}\right)$ & $\begin{array}{c}\text { E/S } \\
(\% d w \text { algae })\end{array}$ & \\
\hline 1 & 180 & 25 & 2.5 & ${ }^{\text {bc }} 53.9 \pm 1.9$ \\
\hline 2 & 270 & 37.5 & 2.5 & cde $51.7 \pm 2.5$ \\
\hline 3 & 180 & 50 & 2.5 & ab $57.5 \pm 2.1$ \\
\hline 4 & 90 & 37.5 & 2.5 & $\mathrm{f} 35.6 \pm 4.0$ \\
\hline 5 & 90 & 25 & 5 & e $46.1 \pm 6.8$ \\
\hline 6 & 270 & 25 & 5 & cde $49.6 \pm 1.6$ \\
\hline 7 & 90 & 50 & 5 & de $48.4 \pm 2.9$ \\
\hline 8 & 270 & 50 & 5 & de $48.0 \pm 2.8$ \\
\hline 9 & 180 & 25 & 7.5 & bc $54.0 \pm 1.4$ \\
\hline 10 & 270 & 37.5 & 7.5 & ab $56.5 \pm 2.5$ \\
\hline 11 & 180 & 50 & 7.5 & a $59.4 \pm 1.6$ \\
\hline 12 & 90 & 37.5 & 7.5 & $\mathrm{f} 40.4 \pm 1.7$ \\
\hline 13 & 180 & 37.5 & 5 & bcd $52.4 \pm 3.0$ \\
\hline
\end{tabular}

Values are means $\pm S D(n=9)$

Values with different superscript letters are significantly different $(p<0.05)$ according to the Fisher LSD test. The order of letters is correlated with the extraction yield.

Table 5: EAE conditions and responses for the extraction yield of water-soluble compounds from S. chordalis after the application of experimental design with P1. 
$\mathrm{EAE} \%=34.4-1.202 \times \mathrm{T}+0.405 \times \mathrm{t}-1.42 \times(\mathrm{E} / \mathrm{S})+0.02 \times \mathrm{T}^{2}-0.001 \times$ $\mathrm{t}^{2}+0.145 \times(\mathrm{E} / \mathrm{S})^{2}-0.001 \times \mathrm{T} \times \mathrm{t}+0.014 \times \mathrm{T} \times(\mathrm{E} / \mathrm{S})+0.001 \times \mathrm{t} \times(\mathrm{E} / \mathrm{S})$

This model was generated using the regression coefficients with statistical significance up to $5 \%$ probability level. The statistical results for the water-soluble compounds extraction showed a coefficient of determination value of $\mathrm{R}^{2}=0.69$ that indicated that the model as fitted can explain almost $70 \%$ of the enzyme-assisted extraction yield variability. The model predicted optimal extraction conditions with the desirability of $96.6 \%$ for a maximum yield of $59.7 \%$ and for an extraction performed at $50^{\circ} \mathrm{C}$, for $200 \mathrm{~min}$ and with $7.5 \%$ of $\mathrm{P} 1$ on dry matter of S. chordalis.

Three-dimensional graphs showing the effect of time, ratio E/S, and temperature are illustrated in Figure 2. For each graph, one of the three optimal parameters was fixed.

After around $200 \mathrm{~min}$, the extraction yield does not seem to increase anymore. According to the results in Table 5 and in Figure 2, the extraction time played a dominant role in the process to increase the number of water-soluble compounds. The influence of the relation $\mathrm{E} / \mathrm{S}$ and the temperature of extraction were insignificant within the experimental range (data not shown).

\section{Validation for a better extraction yield}

The results after the EAE under optimal conditions are reported in Table 6. Under such conditions, for a $200 \mathrm{~min}$ extraction at $50^{\circ} \mathrm{C}$ with an enzyme/substrate ratio of $7.5 \%$, the extraction yield reached $57.9 \%$, which is among the highest values compared to those obtained with the experimental design (Table 5). Moreover, this extraction yield is between the lower and upper limits (54.8-64.6\%). Thus, the statistical model was checked and validated.

The optimization of extraction conditions allowed an insignificant gain of $4 \%$. The values obtained throughout the whole study for focused responses, i.e., the extraction yield, the biochemical composition of extracts, and their antiviral activity, are summarized in Table 7.

Concerning the quality of extracts obtained, namely their biochemical composition, the extract after the action of P1 and after the optimization of extraction conditions is richer in organic matter especially in proteins $(14.7 \%)$ and less in mineral matter (ash). Furthermore, the antiviral activity is kept.

\section{Discussion}

\section{Composition of $S$. chordalis}

The composition of the dry weight of $S$. chordalis is in agreement with previous studies, but only little information is known. Bondu et al. find a dry matter rate of $14.6 \%$ and Hardouin et al. $11.6 \%$ for the same species $[2,3]$. Compared to this previous study, ash content was higher in our study (43.3\%). Fast-growing algae, responsible for seaweed blooms, such as Ulva sp., Gracilaria sp. and S. chordalis, reflect the abundance of nitrogen and other non-organic elements [14]. These chemical elements are naturally abundant and can be found more readily on eutrophic coasts, depending on fluctuating environmental factors and human activities. Polysaccharides represent a high proportion of the dry weight of many macroalgae. In Porphyra $s p$., about $46 \%$ of the dry matter is constituted by carbohydrates, as well as in Palmaria palmata (45 to $74 \%$ of the dry weight) $[15,16]$. The percentage concentrations of neutral sugars, uronic acids, sulfate groups, and protein contents in the dry weight of Solieria chordalis were in line with results of the previous study on the same seaweed [3] and with the study of Khanzada et al. [17], who find a percentage between 25 and $32 \%$ of proteins in Solieria robusta collected in Pakistan. The presence of uronic acids in polysaccharides isolated from Rhodophyta has been reported in a few cases [18].

\section{Solubilization of algal compounds}

Enzymes produced from microorganisms can be used to digest seaweeds by breaking down cell walls that release the cell content in water $[4,6]$. The strategy employed in this study was first to screen different commercial solutions of enzymes with different activities on the same substrate and in identical conditions $\left(50^{\circ} \mathrm{C}, 180 \mathrm{~min}\right.$ and $5 \% \mathrm{E} / \mathrm{S}$ ). To compare the effect of these enzymes, expected responses were focused on the extraction yield, the biochemical composition of extracts, and their antiviral activity.

Similar conditions $\left(50^{\circ} \mathrm{C}, 300 \mathrm{~min}\right.$ and $\left.5 \% \mathrm{E} / \mathrm{S}\right)$ were applied to $S$. chordalis in a previous study [3]. In our study, the extraction yield of the blank reaches $40 \%$ while Hardouin et al. [3] found around $15 \%$. They tested six enzymes, two proteases, and four carbohydrases, and their extraction yields ranged between 15 and $25 \%$ of dry matter. Only two parameters varied between the two studies: the time of extraction and the month of the seaweed collection. Shen et al. conducted studies on tea protein extraction using enzyme methods, and they optimized extraction conditions, notably by testing the time. They showed that this parameter has a positive role. Nevertheless, after 4-8 hours, the effect of extraction time became less significant [19]. Moreover, the biochemical composition of raw material is an important parameter to
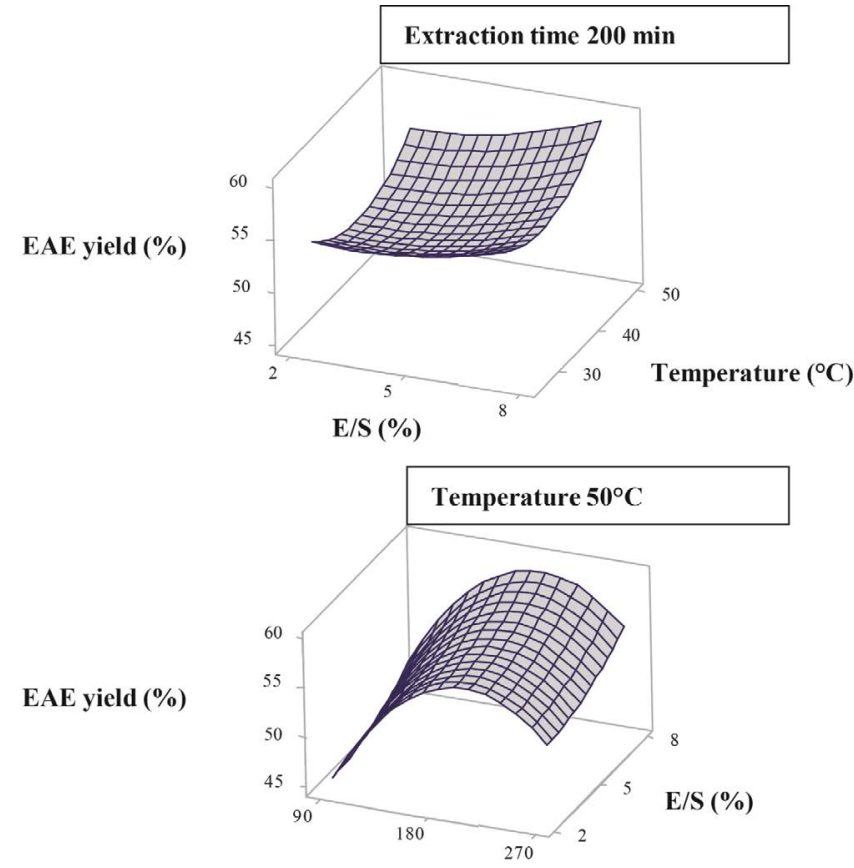

Extraction time (min)

\section{E/S $7.5 \%$}

Figure 2: Estimated response surfaces according to the time, to the enzyme/substrate ratio and to the temperature of extraction in presence of $\mathrm{P} 1$. 


\begin{tabular}{|c|c|c|c|c|}
\hline Response & Prediction & Lower limit (95 \%) & Upper limit (95\%) & Value obtained after experiment \\
\hline EAE yield $(\% d w)$ & 59.7 & 54.8 & 64.6 & $57.9 \pm 2.0$ \\
\hline
\end{tabular}

Table 6: Values predicted statically according to optimal conditions and values obtained after experiments.

\begin{tabular}{|c|c|c|c|c|}
\hline & & Control & $\begin{array}{l}\text { Enzyme-assisted } \\
\text { extraction }\end{array}$ & \\
\hline & & Blank & Without optimization & After optimization \\
\hline Temperature $\left({ }^{\circ} \mathrm{C}\right)$ & & 50 & 50 & 50 \\
\hline Hydrolysis time (min) & & 180 & 180 & 200 \\
\hline E/S ratio $(\%)$ & & 0 & 5 & 7.5 \\
\hline Extraction yield (\% dw of algae in soluble extract) & & b $43.1 \pm 4.5$ & a $55.8 \pm 0.8$ & a $57.9 \pm 2$ \\
\hline \multirow[t]{6}{*}{ Biochemical composition ( $\%$ dw of soluble extract) } & Neutral sugars & b $12.8 \pm 0.1$ & a $27.5 \pm 0.3$ & b $13.1 \pm 0.8$ \\
\hline & Uronic acids & a $1.1 \pm 0.1$ & ${ }^{\mathrm{b}} 0.3 \pm 0.2$ & a $1.3 \pm 0.1$ \\
\hline & Sulfate groups & b $1.6 \pm 0.4$ & a $3.2 \pm 0.1$ & b $1.7 \pm 0.3$ \\
\hline & Proteins & ${ }^{\circ} 4.5 \pm 0.4$ & b $8.9 \pm 2.0$ & a $14.7 \pm 2.8$ \\
\hline & Ash & a $70.9 \pm 1.0$ & b $56.5 \pm 1.6$ & ${ }^{c} 51.3 \pm 2.2$ \\
\hline & Others & b $9.2 \pm 1.7$ & b $3.6 \pm 4.2$ & a $17.9 \pm 6.2$ \\
\hline Anti-HSV activity (EC50 in $\mu \mathrm{g} / \mathrm{mL})$ & & b $170.7 \pm 11.9$ & a $86.0 \pm 9.1$ & b $163.9 \pm 2.8$ \\
\hline
\end{tabular}

For each line, values with different superscript letters are significantly different $(p<0.05)$ according to the Fisher LSD test. The order of letters is correlated with the quantity of compounds or with the efficiency of antiviral activity.

Table 7: Summary of EAE conditions and results for water-soluble compounds extraction yield, biochemical composition of extracts and their antiviral activity throughout the optimization process with P1.

consider for extraction. Hardouin et al. [3] found more neutral sugars (around $10 \%$ more) than in the present study. Various polysaccharides are found in large quantities, and their bonding with glycoproteins in the cell wall reduces the efficiency of water extractions [5]. The quantity of neutral sugars contributing to the base of polysaccharides slows down the extraction and the action of enzymes.

The nature of components of the seaweed cell wall is well known, contrary to their organization in three dimensions. Proteases seem to be the most efficient in the release of compounds. In our study, the maximum extraction yield reached up to $60 \%$ with the protease P1 (Figure 2). P1 is a subtilisin protease. Cleavage by subtilases or serine proteases may be an essential step in breaking down the cell wall of seaweeds by a selective degradation of structural proteins. The red macroalgae possess the most important protein content compared to the other groups (green and brown seaweeds). In Palmaria palmata and Porphyra tenera, 8 to $47 \%$ of proteins are found in the dry matter. Among these proteins, between 2.9 and $6.2 \%$ of total amino acids are represented by serine [20]. Serine and threonine may participate in a peptide-O-glycosidic linkage of the extracellular mucilage of red seaweeds. The serine protease $\mathrm{P} 1$ probably attacks the serineglycoproteins of the cell wall. Glycoproteins with serine residue would play a fundamental role in the structure and in the organization in three-dimensions of the red seaweed cell wall. More studies on the red seaweed cell wall need to be conducted to understand and to improve the action of applied enzymes.

Compounds of the cell wall and of the intracellular medium are then released. Soluble, free and active compounds in water are an advantage for applications of the extracts obtained. The use of enzymes improves the availability and the digestibility of seaweed compounds in a water-soluble extract [5]. According to the nature, the specificity, and the selectivity of enzymes, the biochemical compositions of extracts are different. In line with previous studies, the use of enzymatic liquefaction of red seaweeds could be a useful alternative to enhance the sulfated saccharides and the protein solubilization in mild conditions that are useful for diverse applications $[4,6,21]$.

\section{Release of antiviral compounds}

A Herpes Simplex Virus type 1 (HSV-1), a DNA enveloped virus, is widely spread in the world. It infects between 60 and up to $95 \%$ of certain populations and may cause various illnesses and lifethreatening diseases mainly in immune-suppressed individuals such as transplant recipients and cancer and AIDS patients [22]. Sulfated polysaccharides like carrageenans are known to exhibit a viral inhibitory activity [21]. Our results (Table 4) support this affirmation. A positive correlation between the neutral sugar content and the antiviral activity is perceptible. Soluble extracts obtained with P1, P3, C1, C2, $\mathrm{C} 3$, and C5 were anti-HSV active with no significant difference in their $\mathrm{EC}_{50}$ (86 to $113.7 \mu \mathrm{g} / \mathrm{mL}$ ). These extracts contain more than $23 \%$ of sulfated polysaccharides in their dry matter, contrary to the blank and to the extracts after the actions of P2 and C4. Additionally, before the evaluation of antiviral activity, the cytotoxicity of extracts on Vero cells was examined, using the neutral red incorporation with a view to detecting lysosomal functionality. All extracts were well tolerated by Vero mammalian cells. Kulshreshtha et al. [7] have shown an antiviral activity with an enzymatic extract of Chondrus crispus with an $\mathrm{EC}_{50}$ of $161.1 \mu \mathrm{g} / \mathrm{mL}$, and Hardouin et al. [3] found a $\mathrm{EC}_{50}$ between 23 to $101.1 \mu \mathrm{g} / \mathrm{mL}$ with soluble extracts of $S$. chordalis. All these antiherpetic activities obtained with red seaweed extracts are less efficient than the reference molecule Acyclovir (ACV). However, the occurrence of ACV-resistant mutants highlights the necessity to research for new antiviral compounds [22]. The anti-HSV-1 activity of extracts can be enhanced by purifying water-soluble sulfated polysaccharides [23].

\section{Influence of extraction parameters}

An experimental design was used to study the influence of different parameters on the water-soluble components extraction conditions. Experiments were realized with the same sample of $S$. chordalis and with the protease P1 with respect to the previous results, e.g. best extraction yield, a biochemical composition rich in organic matter, and an effective antiviral activity.

As observed in Figure 2, an increase in the release of the total water-soluble compounds number was obtained when the extraction 
time was increased up to $200 \mathrm{~min}$, whereas at a longer time (270 $\mathrm{min})$, the extraction yield remained practically the same. Nevertheless, many studies have carried out extraction with enzymes for 12-48 hours [6]. Time plays an important role in the quantity of released compounds in the short term and in the quality of these compounds in the long term. Enzymes attack first the algal biomass to release simple compounds, and with time, they access to solubilized compounds and transform them into lower molecular weight compounds.

However, the proportion of neutral sugars after optimization decreased in the present study, while the proportion of non-detected compounds increased (Table 7). This result may be explained by the solubilization of non-quantified sugars from sulfated polysaccharides. In the optimized conditions, the time of extraction is longer and the ratio E/S more important. In the opposite, the protein level increased when optimized parameters were applied. A hypothesis consisting in the formation of agglomerates between proteins and sulfate polysaccharides may explain the lower level of sulfate groups and neutral sugar contents in the WSE after optimization with P1.

Furthermore, more soluble compounds were extracted at $50^{\circ} \mathrm{C}$. Nevertheless, working at $25^{\circ} \mathrm{C}$ seems to be as effective as at $50^{\circ} \mathrm{C}$. This observation was also made by Dumay et al. [5]

Concerning the ratio E/S, results have shown that the more enzymes are added, the more important is the extraction yield, whereas no significant difference was perceptible with a ratio of 2.5 and $7.5 \%$ (samples $\mathrm{N}^{\circ} 3$ and 11 in Table 5).

Algal material is not the appropriate and specific substrate for enzymatic activity. In our study, the enzymes facilitate the liquefaction and the solubilization of water-soluble organic compounds. This type of RSM required fewer experiments and facilitated the arrangement and the interpretation of the effects of the parameters tested. Some unexpected results for certain extraction conditions were found, and they would be worth testing to anticipate the industrial scale for lower costs in energy and in enzymes.

\section{Environmentally-friendly alternative}

The statistical model for predicting the optimization response values was checked by using the selected optimal conditions (Table 6). The quantity of available water soluble compounds from $S$. chordalis increased significantly by $30 \%$ after the action of the enzyme P1 and non-significantly by $4 \%$ after optimization (Table 7 ). However, the extraction conditions for enzyme screening were already close to the optimal conditions. The optimization of extraction conditions confirmed the efficiency of the enzyme-assisted extraction by the repeatability of extraction yields. The antiviral activity is kept after the optimization, but it is significantly less important, which can be explained by the smaller proportion of available sulfated saccharides in extracts.

In conclusion, our study confirms that enzyme-assisted extraction can be used as a promising alternative and sustainable technique to recover active compounds. Compared to an aqueous extract in the same conditions, all the commercial enzyme solutions were more effective in the release of water-soluble compounds. The choices of the nature and of the concentration of enzymes are important as well as the conditions of extraction and the biochemical composition of the raw material. The response surface is a useful and powerful methodology to analyze the influence of different parameters simultaneously on the same algal material that impact directly on the quality and on the quantity of extracted active compounds. Obtained extracts have shown antiherpetic activities with $\mathrm{EC}_{50}$ between 86.0 and $163.9 \mu \mathrm{g} \cdot \mathrm{mL}^{-1}$. This activity would be enhanced by investigating the benefit that the parameters of extraction can bring to the target sulfated saccharides. This study could serve as a base for increasing the quantity of active water-soluble compounds extracted from proliferative seaweeds. Further research focusing on the scale-up of the process design and on the optimal conditions for specific active compounds extraction is highly recommended.

\section{Acknowledgments}

This work has received financial support from the single Inter-Ministry Fund (FUI) within the VB2 project (Valorization of Breton Biomass). The authors than the members of LBCM and of the project VB2 for their help in collecting seaweeds, especially Christel Marty for the maintenance of the cell line and of the virus, Declan Bennett, an undergraduate student from the National University of Ireland, Galway for helping in the analyses of the biochemical composition of seaweed extracts and Nicole Geslin for proof-reading. The authors have no conflict of interest to declare.

\section{References}

1. 1. Bourgougnon N, Stiger-Pouvreau V (2011) Chemodiversity and bioactivity within red and brown macroalgae along the French coasts, Metropole and Overseas Departements and Territories. In: Kim SK (ed) Handbook of Marine Macroalgae. John Wiley \& Sons, Ltd, Chichester, UK

2. Bondu S, Deslandes E, Fabre MS, Berthou C, Li YG (2010) Carrageenan from Solieria chordalis (Gigartinales) Structural analysis and immunologica activities of the low molecular weight fractions. Carbohyd Polym 81: 448-460.

3. Hardouin K, Burlot AS, Umami A, Tanniou A, Stiger-Pouvreau V et al. (2014 Biochemical and antiviral activities of enzymatic hydrolysates from different invasive French seaweeds. J Appl Phycol 26: 1029-1042.

4. Wijesinghe WAJP, Jeon YJ (2012) Enzyme-assistant extraction (EAE) of bioactive components: A useful approach for recovery of industrially important metabolites from seaweeds. A review Fitoterapia 83: 6-12.

5. Dumay J, Clément N, Morançais M, Fleurence J (2013) Optimization of hydrolysis conditions of Palmaria palmata to enhance R-phycoerythrin extraction. Bioresource Technol 131: 21-27.

6. Hardouin K, Bedoux G, Burlot AS, Nyvall Collén P, Bourgougnon N (2014) Enzymatic recovery of metabolites from seaweeds: potential applications. In Bourgougnon N (ed) Sea Plants. Academic Press, Elsevier Ltd., Oxford, UK.

7. Kulshreshtha G, Burlot AS, Marty C, Critchley A, Hafting J et al. (2015) Enzymeassisted extraction of bioactive material from Chondrus crispus and Codium fragile and its effect on Herpes simplex virus (HSV-1). Mar Drugs 13: 558-580.

8. Zhu Y, Li Q, Mao G, Zou Y, Feng W et al. (2014) Optimization of enzymeassisted extraction and characterization of polysaccharides from Hericium erinaceus. Carbohyd Polym 101: 606-613.

9. Dubois M, Gilles KA, Hamilton JK, Rebers PA, Smith F (1956) Colorimetric method for determination of sugars and related substances. Anal Chem 28 . 350-356.

10. Blumenkrantz N, Asboe-Hansen G (1973) New method for quantitative determination of uronic acids. Anal Biochem 54: 484-489.

11. Jaques LB, Ballieux RE, Dietrich CP, Kavanagh LW (1967) A microelectrophoresis method for heparin. Can J Physiol Pharm 46: 351-360.

12. Smith PK, Krohn RI, Hermanson GT, Mallia AK, Gartner FH et al. (1985) Measurement of protein using bicinchoninic acid. Anal Biochem 150: 76-85

13. Langlois M, Allard JP, Nugier F, Aymard M (1986) A rapid and automated colorimetric assay for evaluating in the sensitivity of Herpes simplex strains to antiviral drugs. J Biol Stand 14: 201-211.

14. Teichberg M, Fox SE, Olsen YS, Valiela I, Martinetto P et al (2010) Eutrophication and macroalgal blooms in temperate and tropical coasta waters: nutrient enrichment experiments with Ulva spp. Glob Change Biol 16 2624-2637.

15. Morgan KC, Wright JLC, Simpson FJ (1980) Review of chemical constituents of the red alga Palmaria palmata (dulse). Econ Bot 34: 27-50

16. Nisizawa K, Noda H, Kikuchi R, Watanabe T (1987) The main seaweed foods in Japan. Hydrobiologia 41: 5-29. 
Citation: Anne-Sophie B, Gilles B, Nathalie B (2016) Response Surface Methodology for Enzyme-Assisted Extraction of Water-Soluble Antiviral Compounds from the Proliferative Macroalga Solieria chordalis. Enz Eng 5: 148. doi:10.4172/2329-6674.1000148

17. Khanzada AK, Kazi WSTG, Kabir S, Soofia S (2007) Antifungal activity, elemental analysis and determination of total protein of seaweed, Solieria robusta (Greville) Kylin from the coast of Karachi. Pak J Bot 39: 931-937

18. Bourgougnon N, Lahaye M, Chermann JC, Kornprobst JM (1993). Composition and antiviral activities of sulfated polysaccharide from Schizymenia dubyi (Rhodophyta, Gigartinales), Bioorg Med Chem Lett 3: 1141-1146

19. Shen L, Wang X, Wang Z, Wu Y, Chen J (2008) Studies on tea protein extraction using alkaline and enzyme methods. Food Chem 107: 929-938

20. Lourenço SO, Barbarino E, De-Paula JC, Pereira LO da S, Marquez UML (2002) Amino acid composition, protein content and calculation of nitrogen-toprotein conversion factors for 19 tropical seaweeds. Phycol Res 50: 233-241
21. Prajapati VD, Maheriya PM, Jani GK, Solanki HK (2014) Carrageenan: A natural seaweed polysaccharide and its applications. Carbohyd Polym 105 97-112.

22. Santos MGM, Lagrota MHC, Miranda MMFS, Yoneshigue-Valentin Y, Wigg MD (1999) A screening for the antiviral effect of extracts from Brazilian marine algae against acyclovir resistant Herpes Simplex Virus Type 1. Bot Mar 42 227-230

23. Bouhlal R, Haslin C, Chermann JC, Colliec-Jouault S, Sinquin C et al. (2011) Antiviral activities of sulfated polysaccharides isolated from Sphaerococcus coronopifolius (Rhodophytha, Gigartinales) and Boergeseniella thuyoides (Rhodophyta, Ceramiales). Mar Drugs 9: 1187-1209
Citation: Anne-Sophie B, Gilles B, Nathalie B (2016) Response Surface Methodology for Enzyme-Assisted Extraction of Water-Soluble Antivira Compounds from the Proliferative Macroalga Solieria chordalis. Enz Eng 5: 148. doi:10.4172/2329-6674.1000148
OMICS International: Publication Benefits \& Features

\section{Unique features:}

- Increased global visibility of articles through worldwide distribution and indexing

- Showcasing recent research output in a timely and updated manner

- Special issues on the current trends of scientific research

Special features:

- $700+$ Open Access Journals

$50,000+$ editorial team

Rapid review process

Quality and quick editorial, review and publication processing

Indexing at major indexing services

Sharing Option: Social Networking Enabled

Authors, Reviewers and Editors rewarded with online Scientific Credits

Better discount for your subsequent articles

Submit your manuscript at: http://www.omicsgroup.org/iournals/submission/ 